\title{
OCULAR CHANGES IN THE BLOCH-SULZBERGER SYNDROME (INCONTINENTIA PIGMENTI)*
}

\author{
BY
}

\author{
J. GRAHAM SCOTT, A. I. FRIEDMANN, M. CHITTERS, \\ AND W. J. PEPLER
}

Johannesburg

THE Bloch-Sulzberger syndrome is a familial condition consisting chiefly of ectodermal defects, of which changes in the skin, nails, hair, teeth, central nervous system, and eyes are the most common. The final dermal phase "incontinentia pigmenti" has received the most attention. This disease can be described as a rare and peculiar abnormality of development found almost exclusively in females at birth or shortly afterwards; it usually begins as an inflammatory eruption of the skin tending to assume a linear or racemose pattern. This phase is succeeded or accompanied by the characteristic pigmentary disturbance (Fig. 1), which may, however, occur without the preceding inflammation.

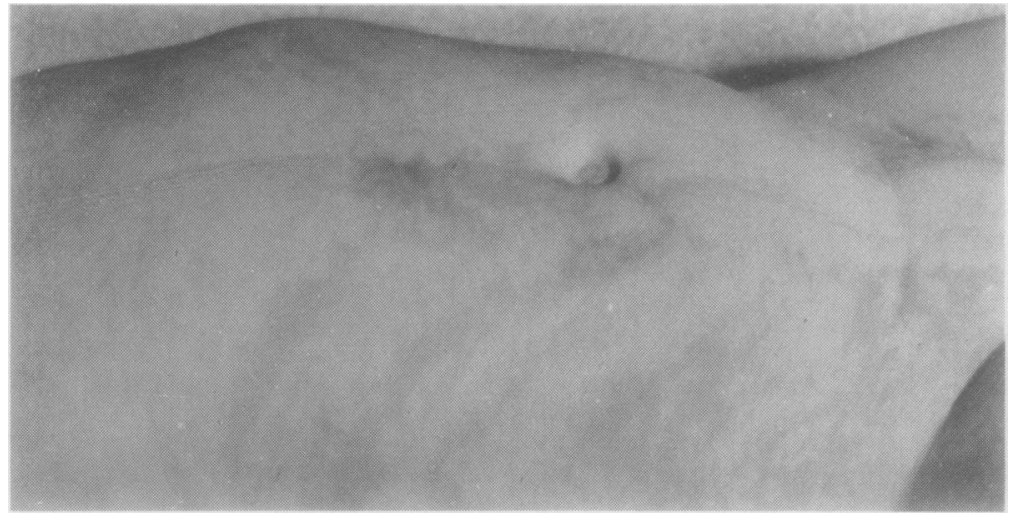

FIG. 1.-Characteristic appearance of " incontinentia pigmenti ".

\section{Review of the Literature}

The first reference that we can find in the literature is that of Garrod (1906), who mentions " peculiar pigmentation of the skin in an infant". Similar cases were presented by Adamson (1907a, b), and the name "incontinentia pigmenti" was given by Bloch (1926). Sulzberger (1928) followed up Bloch's case, and 10 years later Sulzberger and others (1938) suggested that "incontinentia pigmenti" was part of a syndrome of other familial ectodermal defects.

On clinical and genetic grounds Franceschetti and Jadassohn (1954) differentiated two groups: "Bloch-Sulzberger" and "Naegeli". In a thorough review of the

- Received for publication November 27, 1954. 
literature they collected 73 cases of the Bloch-Sulzberger type to which the following eighteen may beadded: the case of Garrod(1906); the case of Ormerod presented by Adamson (1907b); the case of Wilson (1941) which later developed pigmentation (Epstein and others, 1952); an unpublished case of Loewenthal seen by one of us (J.G.S.); seven cases recently published by Brunsting and Eyster (1952), Fisher and Dexter (1953), Joaquin Pedrera (1953), Falk and Hetreed (1953), Cormie (1953), Murray-Will (1954), and Lewis (1954); and seven new cases from the Japanese literature reviewed by Kitamura and others (1954). This brings the total to 91. Only one of these patients was born prematurely (Franklin, 1952) and only one case occurred without doubt in a male (Moncorps-Seidlmayer, 1942) $\dagger$, though four others have been recorded (Almkvist, 1928; Sobel, 1948; Cormie, 1953; Lewis, 1954). We have not included the cases of Asboe-Hansen (1953) and Sachs (1954) as they were not diagnosed as "incontinentia pigmenti". Dr. Buchholz writes to us that there is some doubt about the diagnosis of his case (Buchholz, 1950), but we have accepted it pending confirmation.

Ocular Malformations.-Excluding the reports of blue sclerae by Sulzberger and Bloom (1948) and Haber (1952) and of myopia by Loveman and others (1952) and Rein and Weidman (1952), we find that 23 of the 91 reported cases had ocular defects.

One nystagmus (Haber, 1952).

Five strabismus (Lechleutner-Siemens, 1929; Pierini and others, 1945; Heilesen, 1948; Carney, 1951; Higuchi and others, 1952).

Five cataract (Sulzberger, 1938; Jaramillo and others, 1948; Curth, 1949, Gasteiger, 1951; and Ito 1951).

Four atrophy of the optic nerve (Moncorps-Seidlmayer, 1942; Seidlmayer-Höra, 1943; Gerard-Lapière, 1951; and Carney, 1951).

One suspected papillitis (Kühling, 1949).

The remaining seven can be grouped together as having " a mass in the orbit".

One metastatic ophthalmia (Kawamura, 1954).

Three retrolental fibroplasia (Uebel, 1950; Findlay, 1952; Watanabe, 1954).

Three pseudo-glioma (Bloch-Sulzberger-Franceschetti and Jadassohn, 1954; Haxthausen, 1945; Duke University, 1948).

Some of the patients had more than one ocular abnormality, but only the principal one is listed. Ocular malformations in relatives of the respective cases have been reported by Sulzberger (1938), Duke University (1948), Franklin (1952), and Findlay (1952). Four 'eyes were examined histologically (Bloch-Sulzberger, 1928, Haxthausen, 1945; Duke University, 1948; Watanabe, 1954), but the only report available is that of Prof. Haxthausen, which is very similar to our own case.

\section{Case Report}

A baby girl was born normally in October, 1950, when she weighed $7 \mathrm{lb}$. Her mother had had two attacks of influenza during the pregnancy and slight uterine haemorrhages in the last 2 months. It was noticed at birth that the left eye was " not normal ". From 7 to 10 days after birth the patient had convulsions affecting all limbs. At the same time a macular eruption appeared on the arms and legs. The lesions became vesicular and dried up in 2 weeks forming crusts which disappeared later. In a few days these skin changes recurred and kept on recurring. After a few months verrucous lesions also

+ When a case has been followed up by another worker, the names are hyphenated and the later reference given. 
developed on the limbs and pigment began to be deposited all over the body in lines and whorls. This cycle of changes continued until she was 2 years old, when the pigment began to fade.

At five months the patient was admitted to hospital with neck rigidity, arching of the spine, and a temperature of $103^{\circ} \mathrm{F}$. The cerebrospinal fluid was under pressure but was sterile and had only 1 lymphocyte per c.mm. The right eye became red and a specialist diagnosed an intraocular abscess of the left eye and suspected that similar changes were developing in the right eye because the vitreous was hazy and there was retinal oedema on the nasal side of the disc. After a month the condition of the left eye was unaltered and the changes in the right eye less marked. The infant again developed a temperature which was diagnosed as mastoid infection, but no pus was found at operation and she was transferred to the Transvaal Memorial Hospital for Sick Children where the following points were noticed:

(1) the patient was ill-nourished, rather small for her 8 months.

(2) She did not hold up her head, turn herself over in bed, or sit up.

(3) She had difficulty in recognizing her parents by sight although she had been able to do this previously.

(4) Heart, lungs, and abdomen were normal, except that the right side of the chest was more developed than the left. Circumference of the head was $16 \frac{1}{2}$ in. Reflexes were normal except the pupillary ones.

(5) The right pupil was dilated and fixed. The vitreous was hazy but there was no obvious mass. The right disc was pale and both eyes had nystagmoid movements. The left eye had endophthalmitis and was shrinking.

(6) The skin had linear brown-blue pigmentation affecting all areas and there were crusty, hyperkeratotic irregular masses on the extremities.

(7) Blood tests for syphilis were negative. The blood count showed 3,920,000 erythrocytes with some anisocytosis: 16,700 whites: 37 per cent. neutrophiles, 4 per cent. monocytes, 57 per cent. lymphocytes, 1 per cent. eosinophils, 1 per cent. basophils. The sedimentation rate was $22 \mathrm{~mm}$./hr. The urine contained neither porphyrin nor other abnormalities.

At the age of 1 year the eyes were examined by two of us. Searching nystagmoid movements were present. The right eye had a dilated pupil, oval in shape due to posterior synechiae. There were no keratic precipitates and the vitreous was clear. Under a general anaesthetic a grey-yellow smooth mass was seen in the posterior half of the right globe. There was a red reflex around this mass in the periphery but no retinal details could be seen. The left eye had phthisis bulbi and both eyes were white. The mass was thought to be a metastatic endophthalmitis and our opinion was confirmed by Dr. A. Jokl. A few months later the patient was re-admitted to the Childrens' Hospital for a course of antibiotics. The patient was then 18 months of age and, though unable to sit, she could hold up her head and was beginning to talk. The skin presented greyish-brown, linear pigmented lesions following the distribution of the system of Blaschko (1902) of naevus lines. These hyperpigmented areas had marked resemblance to the pattern of marble in many regions. An erythematous, scaly, and hyperpigmented lesion resembling a naevus unius lateris (Fig. 2, opposite) extended from the right buttock in an uninterrupted line down the posterior aspect of the thigh and turned anteriorly over the knee and leg towards the big toe. Thickened horny lesions were present on the second and third toes, and the dorsum of the right foot, also on the dorsum of the third and fifth fingers and the medial aspect of the right hand. Atrophic scars were evident on the right side of the nose, right arm, and left forearm. There was a nummular eczematous patch on the left side of the back. The hair and nails were normal. The only change in the condition of the eyes was that the mass in the right eye was larger and could be directly seen behind the lens. The peripheral rim of red reflex had disappeared. Only three teeth had erupted; two upper and one lower central incisor. An $x$ ray taken 6 months later showed that many deciduous and permanent teeth were absent (Fig. 3, opposite). 


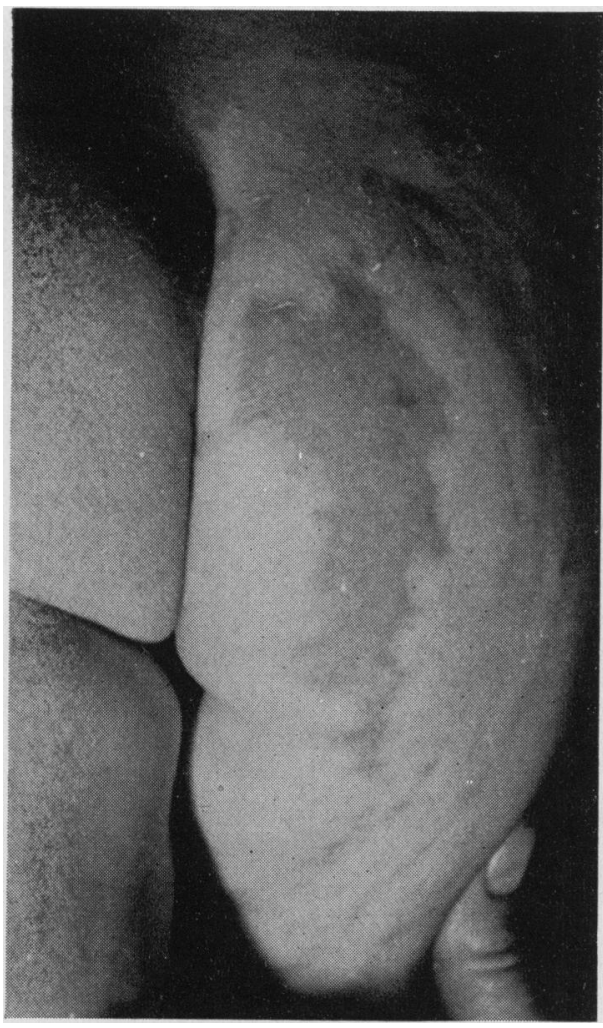

FIG. 2.-Lesion resembling naevus unius lateris.

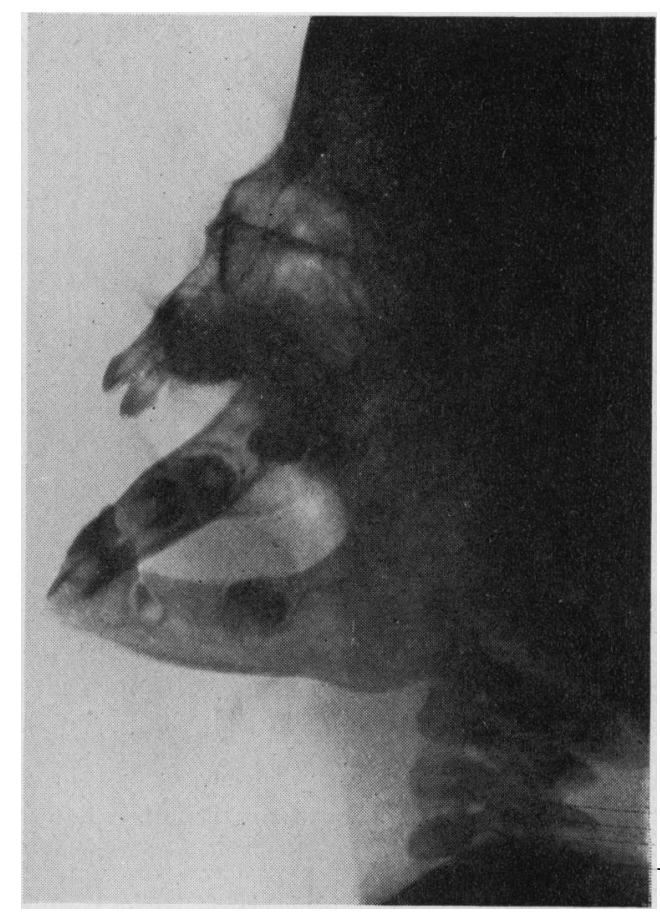

Fig. 3.-Incomplete dentition, $x$ ray at 2 years of age.

Agglutination tests for typhoid and proteus groups were negative. Blood cultures were sterile after 4 days. The urine contained no pus cells and was sterile. The blood count and sedimentation rate were unchanged. The cerebrospinal fluid had 3 polymorphs per c.mm: protein $20 \mathrm{mg}$. per cent.; chlorides $810 \mathrm{mg}$. per cent.; sugar $90 \mathrm{mg}$. per cent.; urea $40 \mathrm{mg}$. per cent. Tests for cerebral syphilis were negative and Lange's colloidal gold test was normal. Culture from infected skin lesions on the right leg grew Staphylococcus aureus which was sensitive to penicillin. The patient was given 100,000 units penicillin and $100 \mathrm{mg}$. terramycin 6-hrly for one week. Neither the skin nor the eyes improved, and the patient ran a temperature of $104^{\circ} \mathrm{F}$., although she did not appear ill and had no symptoms.

In view of the growth of the ocular mass and the lack of response to antibiotics, enucleation of the right eye was advised. The eye and biopsies of the skin were examined histologically, confirming the diagnosis of incontinentia pigmenti. A course of $5 \mathrm{mg}$. ACTH was given 8-hrly for 10 days, but this did not influence the skin lesions and once again the temperature rose to $104^{\circ} \mathrm{F}$. for which no cause could be established.

At the age of 3 the patient had further epileptic fits and her development was slow. She was able to crawl and sit by herself and she had six teeth. By 3 years and 8 months she was able to walk and the pigmented lesions were fading.

\section{Pathological Report}

Eye.-On section, the most striking feature was a completely detached, funnel-shaped, folded, and thickened retina which showed a slight patchy infiltration by lymphocytes (Fig. 4, overleaf). On the medial side only, the detachment involved the pars plana of the ciliary body. Lying between the lens and the detached retina was a thick fibrovascular membrane which was attached to the pars plana retinae on each side. The space behind the retina contained albuminous fluid in which numerous detached retinal pigment epithelial cells (ghost cells) and fatty acid crystals could be 
Frg.4.-Funnel-shaped detachment of the retina in affected eye (section $\times 4$ ).

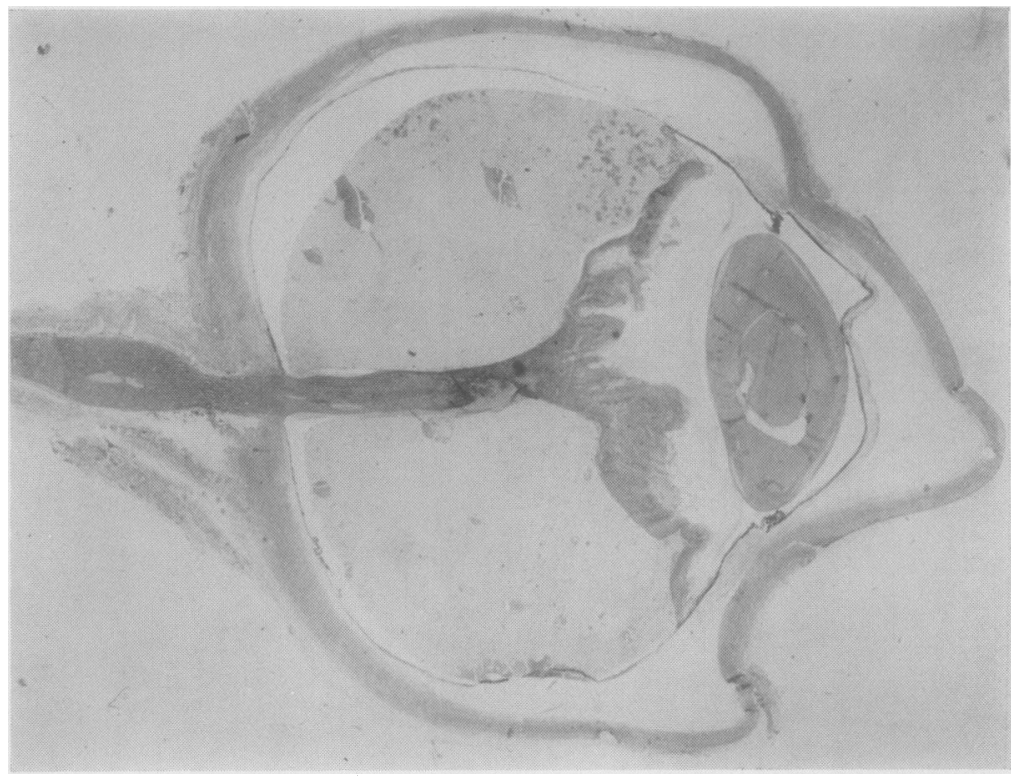

seen. The cornea, the anterior chamber, and the lens, although slightly distorted by sectioning, appeared healthy. The iris showed a large posterior synechia, but no pathological change could be observed in the stroma. There was some oedema and slight infiltration by lymphocytes and an occasional polymorphonuclear leucocyte towards the cut end of the optic nerve.

Skin.-Biopsy specimens were taken from both verrucous and pigmented lesions.

Section of the verrucous lesion (Fig. 5) showed the presence of hyperkeratosis, papillomatosis, and atrophy of the stratum germinativum. There was a peculiar vacuolation of the cells in the

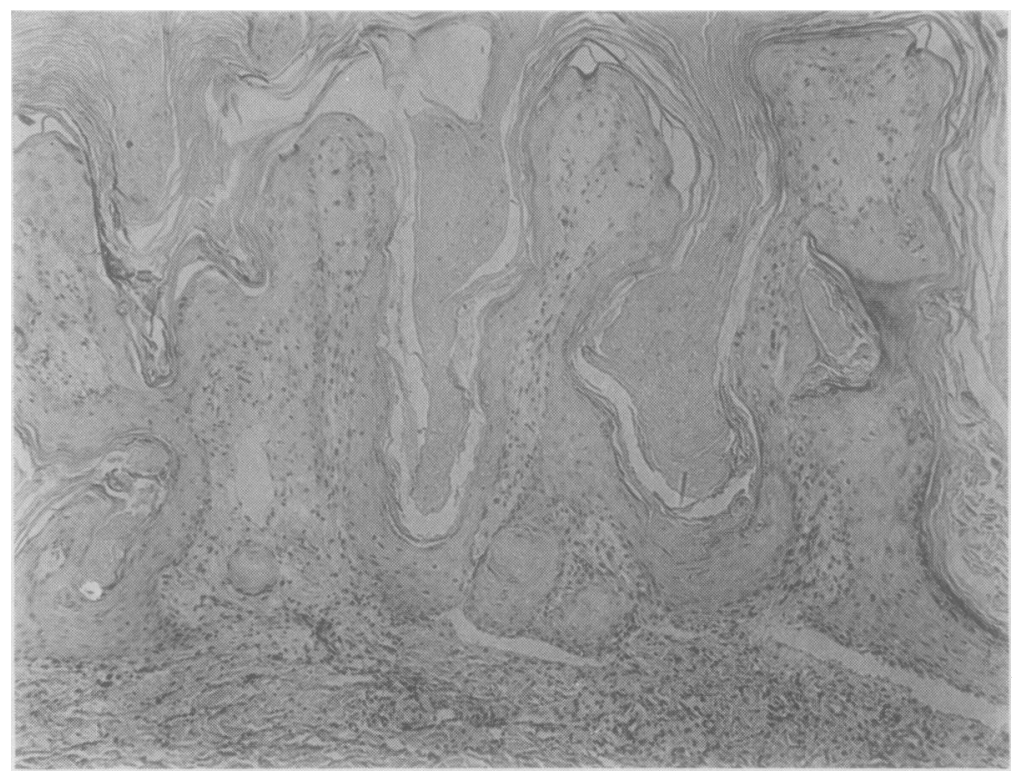

FIG. 5.-Section of verrucous lesion $(\times 70)$.

upper layers of the rete malphigi and the horny layer, giving the latter a basket-weave appearance. The nuclei in these vacuolated cells were pyknotic. The upper corium showed a slight perivascular lymphocytic infiltration and also increased melanin pigment either lying free or contained in chromatophores. 
In the section taken from the pigmented lesion (Fig. 6), the most conspicuous feature was the presence of an increased amount of melanin pigment in the upper corium. Part of the pigment was present in the chromatophores and the remainder was lying free between the collagen fibres. A slight chronic inflammatory cell infiltration was also present around the vessels of the upper corium. The epidermis was slightly atrophic and contained a large number of clear cells with pyknotic nuclei. There was a complete absence of melanin pigment in the basal layer.

FIG. 6.--Section of pigmented lesion $(\times 250)$, showing numerous chromatophores.

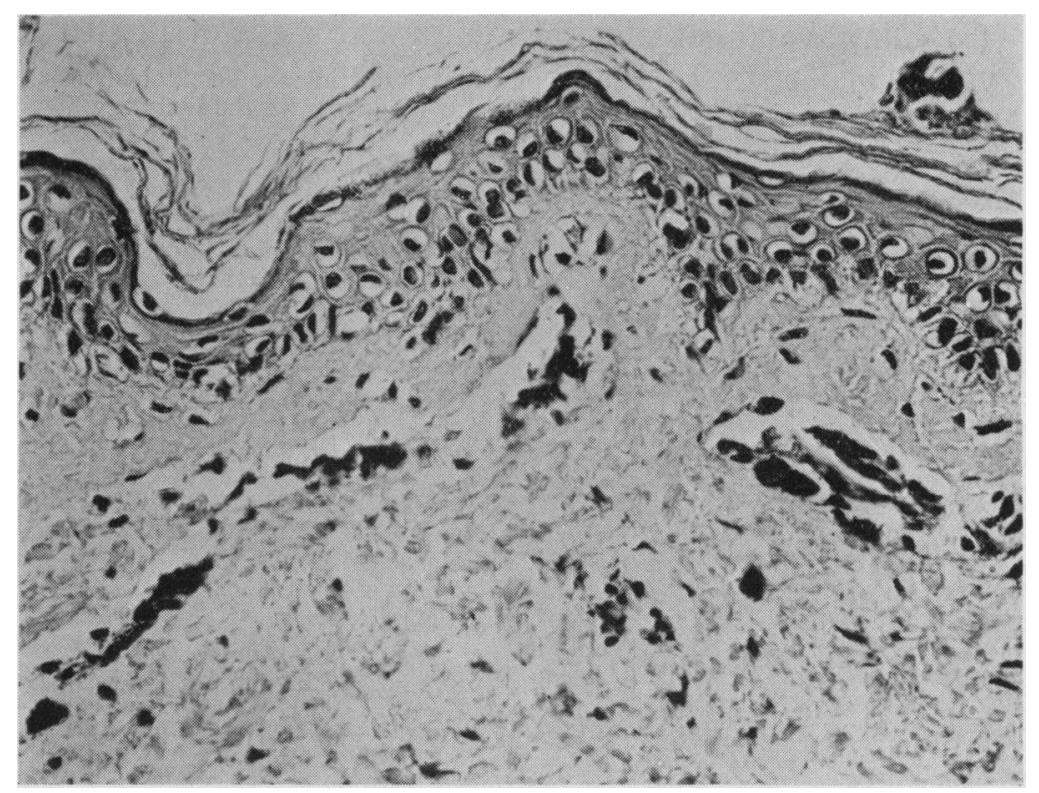

Family History.-Our notes are not yet full enough to throw further light on the mode of inheritance of the Bloch-Sulzberger syndrome. We have been told that many members, have large pigmented birth marks; that one cousin of the patient's mother was born blind, was unable to walk, had fits, and died at 8 years; and that another cousin's daughter was born blind, deaf, and dumb. The maternal grandmother had a posterior polar cataract, and the syndrome has been found in a first cousin by Dr. J. A. Loewenthal.

\section{Discussion}

The most striking ocular malformation in our case and in seven reported cases was " a mass in the orbit". In some cases this presented clinically as a metastatic endophthalmitis, in others as pseudo-glioma, and in the remainder as "retrolental fibroplasia". Some pathological reports are also compatible with the diagnosis of " retrolental fibroplasia", but it would be unfortunate if this led to confusion with the entity induced by hyperoxia in premature babies. We agree with Ashton (1954) that a revision of nomenclature is required when the problem is better understood.

The wide range of defects found in the syndrome may possibly be explained by postulating lesions similar to the hereditary myelocephalic blebs which arise between the embryonic ectoderm and mesoderm in the Little and Bagg mouse strain (Grüneberg, 1947) and affect tissues only at a critical stage of development. 


\section{Summary}

(1) A new case of the Bloch-Sulzberger familial syndrome is presented, with a review of 91 cases in the literature.

(2) Ocular defects such as squint, cataract, or pseudo-glioma have been found in 24 of 92 cases and sometimes in their relatives.

(3) Clinical and pathological studies were made of an affected eye.

We wish to thank Dr. A. E. Strawbaun for conducting the hospital investigations and we are greatly indebted to Professor Franceschetti for his help with the literature.

Adamson, H. G. (1907a). Brit. J. Derm., 19, 198.

\section{REFERENCES}

(1907b). Proc. roy. Soc. Med. (Derm. Sec.), 1, 2.

Almkvist, J. (1928). Quoted by Sulzberger (1928), p. 32.

Asboe-Hansen, G. (1953). Arch. Derm. Syph. (Chicago), 67, 152.

Astron, N. (1954). British Journal of Ophthalmology, 38, 385.

BlaschKo, A. (1902). "Die Nervenverteilung in der Haut in ihrer Beziehung zu den Erkrankungen der Haut". Braumüller, Vienna. Quoted by Fegeler, F., and Kautzky, R. (1952), Arch. Derm. Syph. (Berl.), 194, 614.

Bloch, B. (1926). Schweiz. med. Wschr., 7, 404.

BRunsting, H. A., and Eyster, W. H. (1952). Arch. Derm. Syph. (Berl.), 66, 631.

BuchHolz, A. M. (1950). Chicago Derm. Soc., 18, 10.

Carney, R. G. (1951). Arch. Derm. Syph. (Chicago), 64, 126.

CORMIE, R. L. (1953). Brit. J. Derm., 65, 285.

CURTH, H. O. (1949). J. invest. Derm., 13, 233.

DUKE UNIVERSTY (1948). Baltimore-Washington Derm. Soc., 13, 11.

Epstein, S.. Vedder, J. S., and Pinkus, H. (1952). Arch. Derm. Syph. (Chicago), 65, 557.

FALK, A. B., and HeTreed, F. (1953). Ibid., 67, 530.

Findlay, G. H. (1952). Brit. J. Derm., 64, 141.

Fisher, A. A., and DeXter, D. (1953). Arch. Derm. Syph. (Chicago), 67, 524.

FrancescheTt, A., and JADASSOHN, W. (1954). Dermatologica (Basel), 108, 1.

FranklIN, A. W. (1952). Brit. med. J., 1, 75.

GARROD, A. E. (1906). Trans. clin. Soc. Lond., 39, 216.

GASTEIGER, H. (1951). Ber. Dtsch. ophthal. Ges., 57, 292.

GrüNeberg, H. (1947). "Animal Genetics and Medicine ", p. 62. Hamish Hamilton, London.

HABER, H. (1952). Brit. J. Derm., 64, 129.

HAXTHAUSEN, H. (1945). Acta. derm.-venereol. (Stockh.), 25, 528.

HeILESEN, B. (1948). Ibid., 28, 544.

Higuchi, K., Urabe, H., Hironaka, T., and Hirata, T. (1952). Quoted by Kitamura and others (1954).

Höra, J. (1943). Z Zbl. allg. Path. path. Anat., 81, 52.

ITO, M. (1951). Tohoku J. exp. Med., 54, 67.

Jaramilo, R. Manterola, A., and Rosselot, J. (1948). Rev. chil. Pediat., $19,654$.

JoAQuin Pedrera, J. (1953). Bol. Soc. Cubana Derm. Sif., 10, 124.

KAWAMURA (1954). Quoted by Kitamura and others (1954).

Kitamura, K., Fukushiro, R., and Miyabayashi, T. (1954). Arch. Derm. Syph. (Chicago), $69,667$.

KüHLING, F. (1949). “Incontinentia pigmenti ”. Dissertation, Wurzburg.

LAPIÈRE, S. (1951). Arch. belges Derm. Syph., 7, 156.

LewIS, G. M. (1954). Arch. Derm. Syph. (Chicago), 69, 507.

Loveman, A. B., Fliegelman, M. T., Weidman, A. I., and Rein, C. R. (1952). J. Pediat., 40, 442.

Murray-Will, E. (1954). Aust. J. Derm., 2, 140.

Pierini, L. E., Garcia, L. A., Pomposiello, I., and Rey, O. (1945). Rev. argent. Dermatosif., 29, 181 .

Rein, C. R., and Weidman, A. I. (1952). Arch. Derm. Syph. (Chicago), 65, 361.

SACHS, P. M. (1954). Ibid., 69, 629.

SEIDLMAYER, H. (1942). Z. Kinderheilk., 63, 451.

SiEMENS, H. W. (1929). Arch. Derm. Syph. (Berl.), 157, 382.

Sobel, N. (1948). Arch. Derm. Syph. (Chicago), 58, 467.

SulzBerger, M. B. (1928). Arch. Derm. Syph. (Berl.), 154, 19. and Bloom, D. (1948). Arch. Derm. Syph. (Chicago), 58, 468. , Fraser, J. F., and Hutner, L. (1938). Ibid., 38, 57.

Uebel, H., Ludwig, A., and Korting, G. (1950). Arch. Syph. Derm. (Berl.), 190, 114.

WATANABE (1954). Quoted by Kitamura and others (1954).

Wilson, D. J. (1941). Arch. Derm. Syph. (Chicago), 44, 58. 